Ilmu Dakwah: Academic Journal for Homiletic Studies Vol 10 No 1 Januari-Juni 2016 p-ISSN 1693-0843

Online sejak 21 Juni 2016 di http://journal.uinsgd.ac.id/index.php/idajhs DOI: http://dx.doi.org/10.15575/jid.v10i1.334

\title{
Dakwah pada Masyarakat Teknologi
}

\author{
Aep Kusnawan \\ Fakultas Dakwah dan Komunikasi \\ UIN Sunan Gunung Djati Bandung \\ aep_kusnawan@uinsgd.ac.id
}

\begin{abstract}
Da'wah constantly faced the reality. Reality has a dynamic stance, turned and drove into the future. Analysis of the reality and the trend of future conditions are kenyaaan that all parties drove toward itu. Salah the trend of the future is the development of increasingly complex technology. While each discovery technology has an influence on people. Where human at the same time is also the subject and the object of propaganda. So how propaganda in the technology community needs to be built? For this study trying to look into thinking propaganda of an expert in the field of technology and Muslim cendekiaan, Armahedi Mahzar. The results showed that, first, Thought propaganda Armahedi Mahzar not be separated from the socio hitoris life. Second, Armahedi views on the technology closely related to the shape of the philosophy behind the technology. Third, proselytizing view Armabedi in the technology community, stressed the need tarkiyatunnafs measures at the individual level; Patience and gratitude at the group level, asceticism and faqr at the community level, as well as the development of science based on Tawheed

Keyword: strategy, dakwah, technological society
\end{abstract}

\section{Abstrak}

Dakwah senantiasa dihadapkan pada kenyataan. Kenyataan memiliki sikap dinamis, berubah dan melaju ke masa depan. Analisa terhadap kenyataan dan kecenderungan kondisi masa depan merupakan kenyaaan yang semua pihak melaju ke arah itu.Salah satu kecenderungan masa depan adalah perkembangan teknologi yang semakin kompleks. Sementara setiap temuan teknologi memiliki pengaruh terhadap manusia. Dimana manusia pada saat yang sama juga merupakan subjek dan objek dakwah. Maka bagaimana dakwah pada masyarakat teknologi perlu dibangun? Untuk itu penelitian ini mencoba menelisik pemikiran dakwah dari salah seorang ahli di bidang teknologi dan cendekiawan Muslim, Armahedi Mahzar. Hasil penelitian menunjukan bahwa, Pertama, Pemikiran dakwah Armahedi Mahzar tidak terlepas dari latar belakang sosio hitoris kehidupannya. Kedua, Pandangan Armahedi mengenai teknologi erat kaitannya dengan bentuk filosofi di balik teknologi tersebut. Ketiga, Pandangan dakwah Armahedi pada masyarakat teknologi, menekankan pada perlunya langkah tazkiyatunnafs pada tingkat individu; Sabar dan syukur pada tingkat kelompok, zuhud dan faqr pada tingkat masyarakat, serta pengembangan sains berlandaskan tauhid.

Kata Kunci: strategi, dakwah, masyarakat teknologi 


\section{PENDAHULUAN}

Hampir tidak seorang pun saat ini dapat melepaskan diri dari pengaruh teknologi. Setiap hari manusia bergandengan dengannya, mulai dari pakaian yang dipakai, makanan dan minuman yang dikonsumsi, sampai kepada berbagai aktivitas biasa melibatkan sejumlah teknologi.

Perkembangan teknologi akhir-akhir ini berjalan jauh lebih cepat dari sebelumnya. Teknologi pada masa sebelumnya, memerlukan ratusan ribu tahun untuk pemanfaatan batu, kayu dan tulang kepemanfaatan logam. Memerlukan puluhan ribu tahun untuk dapat mengambil isyarat oral pada penulisan dinding gua, apalagi ke kertas dan percetakan. Akan tetapi semenjak ditemukan mesin cetak oleh Gutenberg, teknologi terkembang seperti deret ukur (Koencaraningrat, 1990: 186).

Penetrasi teknologi pun semakin jauh, yang semula ditemukan dan hanya dimanfaatkan oleh orang-orang tertentu, kini dalam waktu yang reltif singkat telah dapat menjangkau banyak orang dan wilayah yang jauh. Hal demikian menyebabkan teknologi semakin diminati dan kian menjadi pusat perhatian. Pada gilirannya, manusia tidak dapat mengelak dari berbagai pengaruh pesatnya teknologi tersebut. Marwah Daud (1994: 23), pernah melukiskan, bahwa rata-rata perjalanan yang dilakukan oleh orangorang modern dalam sebulan, sama panjangnnya dengan jarak yang dilalui manusia dulu sepanjang sepanjang hidupnya. Begitu juga dalam informasi, jumlah informasi yang harus diolah manusia sekarang dari koran selama seminggu, lebih banyak dari seluruh informasi tertulis yang harus diolah oleh penduduk pada abad pertengahan sebelum ditemukan mesin cetak. Kenyataannya tersebut merupakan bagian kecil dari isyarat bahwa perkembangan pesat teknologi terpengaruh pula kepada kegiatan manusia. Kenyataan itu, memperkuat kedudukan teori sosiologi bahwa, "antara kebudayaan dan struktur masyarakat terdapat hubungan fungsional yang satu menganjurkan yang lain dan sebaliknya (Polak, 1976: 383).

Sejarah teknologi mengungkap, prestasi teknologi sekarang ini merupakan bagian dari prestasi kebudayaan Barat. Barat yang sering dibedakan dengan Timur baik dari segi ideologi, politik, ekonomi, geografi, maupun agama. Sebab, mereka memiliki andil besar dalam pembangunannya. Walaupun prestasi tersebut bukan berarti pangkal melainkan lebih bersifat sebagai mata rantai yang menjadi penghubung masa modern sekarang dengan masa sebelumnya. Sebagaimana Seyyed Hossein Nashr (1994: 186), memandang sains modern yang diciptakan pada masa renaisans, tidak akan mungkin ada tanpa penerjemahan yang

35c Ilmu Dakwah: Academic Journal for Homiletic Studies, Vol. 10 No.1 | Jan-Juni 2016 
dikeluarkan dari bahasa Arab ke Latin pada abad-abad sebelumnya, seperti yang terjadi di Spanyol dan beberapa bagian di Sicilia Italia.

Namun demikian, kesinambungan sains modern yang merupakan bagian dari kebudayaan Barat, tidak berarti memiliki kesamaan dengan sains sebelumnya, yang sering disebut sebagai sains Timur. Keterpisahan terjadi sering dianalisa sebagai produk sejarah yang berbeda. Inti dari keterpisahan mendalam itu, menurut Nasr berakar pangkal pada kenyataan bahwa sains Islam berdasar pada yang dikendalikan oleh kebijakan dan kehendak Allah, serta segala sesuatunya saling terkait satu sama lain yang mencerminkan kesatuan pada tingkat kosmos. Berbeda dengan sains Islam, sains Barat lebih bertumpu kepada pertimbangan bahwa dunia alamiah sebagai sebuah realitas terpisah dari Allah. Hal terbaik menurut Nasr, Allah diterima sebagai pencipta dunia, sementara keterlibatan-Nya dalam pengelolaan dunia dan pemeliharaan-Nya yang berkesinambungan terhadap dunia tidak diterima dalam sudut pandangan sains modern .

Dampak dari akar masalah di atas terlihat dalam perkembangan masyarakat khususnya di Barat, yang diamati oleh Elizabeth K. Nottingham (1993: 51-66), bahwa telah terjadi tiga tahap perkembangan di Barat. Pertama, masyarakat terbelakang yaitu masyarakat kecil terisolasi dan terbelakang. Tingkat perkembangan teknik mereka masih rendah laju perubahan sosial masih lambat agama begitu kuat dianut oleh mereka dan agama memasukan pengaruhnya kedalam sistem masyarakat secara mutlak. Baik dalam bidang ekonomi, politik maupun keluarga. Kedua, masyarakat pra industri yang sedang berkembang, mereka tidak begitu terisolasi, berubah lebih cepat, lebih luas daerahnya dan lebih besar penduduknya dan ditandai tingkat perkembangan teknologi yang lebih tinggi dari pada tingkat perkembangan dan ikatan kepada sistem nilai dalam masyarakat ini, akan tetapi lingkungan yang sakral dengan yang sekuler sedikit-sedikit banyak masih atau sudah dapat dibedakan. Sehingga terdapat kemungkinan bagi timbulnya ketegangan antara sistem nilai keagamaan dan masyarakat secara keseluruhan. Agama bagi mereka merupakan fokus potensial bagi munculnya pembaharuan dan juga kekacauan di masyarakat, atau dalam lebih konkretnya atara kepentingan organisasi politik.

Ketiga, menurut Nottingham adalah masyarakat dinamik,teknologinya tinggi dan semakin berpengaruh terhadap segala aspek kehidupan. Karena seringnya mereka menggunakan metode empirik dalam hal mempelajari ilmu pengetahuan dan teknologi, maka hal tersebut memiliki konsekuensi kepada agama. Dimana lingkungan yang sekuler meluas terus menerus yang seringkali mengorbankan lingkungan yang sakral, sehingga lebih mempersempit kepercayaan dan pengalaman

Ilmu Dakwah: Academic Journal for Homiletic Studies, Vol. 10 No.1 | Jan-Juni 2016357 
keagamaan pada hal yang kecil-kecil saja, seperti kehidupan di gereja dan pada hari tertentu saja, sehingga fungsi agama di masyarakat melemah.

Masyarakat teknologi, seperti yang diistilahkan oleh Armahedi Mahzar (1993: 14), di mana teknologi modern mengalir dari sana dan banyak diimpor oleh negara-negara yang berpenduduk Muslim. Sementara itu kenyataan, negara muslim sedang berusaha dengan gigihnya mengembangkan bidang ilmu pengetahuan dan teknologi tersebut, mengingat IPTEK telah banyak membantu manusia dalam membebaskan mereka dari takhayul dan memerdekakan mereka dari kungkungan berbagai hukum alam.

Apa yang terjadi pada kehidupan di Barat umunya --seperti dijelaskan Notitingham-- tadi yang dilanda skularisme dan pengabaian agama serta pengekangan spiritual untuk tujuan profane. Harvey Cox yang dikutif oleh Rusli Karim (1992: 2), meperkirakan hal tersebut dapat terjadi juga di Indonesia sebagai negara berkembang menuju masyarakat teknologis. Ia merupakan tantangan tersendiri bagi kehidupan beragama, khususnya dalam upaya-upaya penghidupan nilai-nilai agama ditengah masyarakat yang telah terimbasi oleh dampak tenologi modern, atau masyarakat yang sedang mengalami transformasi menuju masyarakat teknologis. Khususnya dalam upaya penghidupan nilai-nilai agama yang lebih dikenal dengan istilah dakwah. Karena dengan dakwah, diharapkan hakikat insaniyah dalam kehidupan manusia dapat terwujud.

Menghadapi masalah di atas, Armahedi Mahzar yang dikenal sebagai seorang cendekiawan muslim, dengan pemikiran yang utama tentang kesatupaduan atau yang disebutnya integralisme, serta pandangannya tentang kehidupan Islam di masa depan. Hal itu memberi peluang untuk penjajakan lebih lanjut. Karena boleh jadi pandangannya akan sangat berguna bagi pembenahan dakwah pada masa yang diliputi oleh kemajuan teknologi tersebut.

Armahedi seorang yang cukup pengalaman di bidang teknologi. Selain sebagai pengajar senior Fisika Teoritik di ITB, ia juga pernah menjadi konsultan peneliti di Lembaga Fisika Nasional, LIPI dan di pusat Reaktor Atom Bandung, BATAN. Armahedi juga seorang yang cukup kental dengan agama, hal tersebut ditandai dengan jabatannya pernah sebagai ketua komisi Filsafat Agama di Ikatan Cendekiawan MuslimOrwil Jabar tahun, disamping sebagai pembicara di berbagai seminar tentang agama dan kebudayaan, yang dikenal sebagai pembicara yang rendah hati. Akan tetapi, "kerendahan hatinya itu, justru cukup sakti untuk meyakinkan semua, bahwa kapasiitas keilmuan seorang Armahedi patut diperhitungkan" (Hikmah, 1/4/1994). 
Barangkali karena pengalaman intelektual di bidang budaya dan teknologi di satu pihak serta bidang agama dan Islam di pihak lain, Armahedi memiliki pandangan yang integral. Armahedi memandang Islam sebagai agama yang sempurna, sebagai ad-Dien yang integral. Integralitas atau kesatupaduannya menyebabkan dia menjadi basis bagi kepaduan perdaban Islam, yang pada gilirannya juga menyatupadukan peradaban manusia yang ada. Kesepaduan peradaban Islam menurutnya, mempunyai susunan berjenjang fleksibel yang menyesuaikan diri dengan perkembangan zaman, begitu pula zaman di mana masyarakat ditandai dengan kemajuan teknologi.

Berdasarkan latar belakang masalah di atas, maka rumusan masalah yang akan diteliti meliputi: latar belakang sosio-koltural yang mengawali lahirnya pemikiran Armahedi Mahzar; Pandangan Armahedi Mahzar mengenai dampak tenologi modern pada masyarakat; Pemikiran Armahedi tentang dakwah pada masyarakat teknologi.

Dari rumusan yang telah diuraikan, maka usaha-usaha penelusuran terhadap pemikiran Armahedi Mahzar tentang dakwah pada masyarakat tekologi, pada gilirannya menuntut studi ini untuk mengetahui berbagai hal yang mendukung.

Penelusuran ini tidak terlepas pada biografi Armahedi. Kemudian kondisi sosiokultural yang diduga memiliki pengaruh pada pemikiran Armahedi. Suatu hal yang tidak terlewatkan adalah penelusuran terhadap pandangannya dalam menyikapi dampak teknologi modern.

Sesuai dengan karakternya, penelitian ini akan menggunakan metode deskriptif pendekatan kualitatif. Hal itu mengingat, dengan menggambarkan apa yang menjadi pemikiran Armahedi Mahzar, nanti akan terlihat wujud kerangka pemikirannya. Selanjutnya pemikiran itu dianalisa dengan menghadirkan sejumlah pemikiran dari tokoh lain yang memiliki tinjauan yang tentang objek termaksud. Disamping tidak ketinggalan, peneliti juga memberikan berbagai analisa pada pemikiran armahedi Mahzar tersebut.

Jenis data dalam penelitian ini meliputi: data tentang latar belakang sosio-koltural pemikiran Armahedi Mahzar; Data tentang pandangan Armahedi Mahzar dalam menyikapi dampak teknologi pada masyarakat; Data tentang pemikiran Armahedi Mahzar tentang Dakwah pada Masyarakat Teknologi.

Sedangkan sumber datanya adalah: Data tentang latar belakang sosio-koltural pemikiran Armahedi Mahzar akan diperoleh dari studi kepustakaan dan dokumen serta wawancara dengan Armahedi Mahzar. Data mengenaui pandangan Armahedi Mahzar tentang dampak teknologi pada masyarakat akan diperoleh dari kepustakaan dan karya-karya

Ilmu Dakwah: Academic Journal for Homiletic Studies, Vol. 10 No.1 | Jan-Juni 2016359 
Armahedi Mahzar. Adapun data mengenai pemikiran Armahedi Mahzar tentang dakwah pada masyarakat akan diperoleh dari kepustakaan dan karya-karya Armahedi Mahzar.

\section{HASIL DAN PEMBAHASAN}

Ilmu dan teknologi lahir, terdorong oleh kebutuhan manusia untuk memenuhi kebutuhan hidupnya, untuk dapat dapat mempertahankan eksisitensinya, yaitu berinteraksi dengan lingkungan hidupnya. Dengan ungkapan lain, makana dikembangkannya ilmu dan teknologi oleh manusia (aspek aksiologis ilmu dan teknologi) ialah sebagai alat, agar manusia dapat memenuhi misi atau mana kehidupannya di dunia.

Misi kehidupan manuisia tersebut, menurut Islam, setidaktidaknya menunjuk empat fungsi kodrati manusia, yaitu: fungsi pengabdian, fungsi kekhalifahan, fungsi kerisalahan, dan fungsi insani (Patiknya, 1991: 11). Hal itu sesuai dengan dasar-dasar: fungsi pengabdian: Q.S. Adz-Dzariyat: 56; Q.S. Al-Bayinah: 5, disamping berdimensi transendental (ibadah khusus), juga recermin pada dimensi khorisontal atau pengabdian kepada sesama manusia dengan amal sholeh (ibadah umum). Fungsi kekhalifahan: Q.S. Al-Baqarah:30 dan Q.S. Al-Anam: 165, menjadi wakil Allah mengelola dan mengatur kehidupan di dunia agar tercapai harmonis dan kesejahteraan. Fungsi kerisalahan: Q. S. Al-Imran: 104 dan Q.S. Al-maidah: 67, menyampaikan kebenaran ajaran Islam sebagai pedoman hidup manusia untuk mencapai keselamatan dan kebahagiaan.

Allah menciptakan manusia sebagai makhluk yang paling baik stukturnya, paling mulia, melebihi dan mengatasi makhluk lain (Q.S. AtTin: 4; Q.S.Al-Isra: 70). Namun demikian sebagian mereka muncul sebagai makhluk yang bersegi negatif, bodoh, dzalim, kikir (Q. S. Al-Ahzab: 772, Al-Isra: 70) atau bahkan menjadi serendah-rendahnya makhluk (Q. S. AtTin: 5). Karena itu manusia adalah makhluk yang paling potensial dan unggul, termulia namun dalam penampilan (aktualisasinya) belum tentu demikian. Dengan begitu, ada semacam kewajiban yang mendasar dalam diri manusia, yaitu mengakualkan keunggulan kualitas tersebut, baik segi fisik, mental, intelektial, maupun spritualnya. Aktualisasi potensi diri sebagai makhluk yang paling super tersebut merupakan fungsi kodrati yang istilah Ahmad Watik sebagai ibsanisasi.

Dengan demikian, setiap kemampuan manusia yang lahir dari potensi dirinya, seperti kebudayaan, lebih khususnya, ilmu dan teknologi sewajarnya dikembangkan dan diperuntukan untuk pemenuhan fungsifungsi di atas. Bagaimana melalui ilmu dan teknologi, manusia benarbenar mampu mengaktualisasikan diri sebagai makhluk yang super, yang mampu menjadi wakil Allah dalam mengelola dunia melalui yang 
mendukung terhadap keinginan martabatnya dihadapan Allah, serta lebih mengintensifkan kemaslahatan di antara sesama manusia dan lingkungannya.

Akan tetapi, perkembangan ilmu pengetahuan dan teknologi modern, telah dikembangkan oleh orang-orang Barat, dengan berbagai budaya yang seperti sekularisme. Pada gilirannya, disatu pihak teknologi modern karena kepositifannya, ia dibutuhkan untuk memenuh fungsifungsi kodrati kemanusiaan, sementara agama dipihak lain merupakan sesuatu yang tidak dikehendaki keinginannya, seperti yang terjadi di Barat. Karena itu, agama dan keragaman yang meliputi kajian tentang konsepkonsep agama, transmisi agama dan pembudayaan agama, merupakan bahan pemikiran dakwah yang tertuntut kedinamisanya untuk dapat menjawab permasalahan di masyarakat. Tidak hanya berkaitan dengan proses yang diolah oleh manusia sehingga menjadi umat beragama, tetapi juga bagaimana agama yang dianut itu dapat terwujud tetap memiliki nilainilai funsional. Bagaimana pula umat beragama dalam perkembangan sejarahnya dapat mengalami transformasi keagamaan, sehingga transformasi itu menjadi untuk keberagamaan mereka.

Tidak hanya itu, dakwah Islam juga diperlukan dalam memberikan perhatian terhadap segala macam usaha yang ditujukan untuk mengolah kenyataan hidup dan kehidupan manusia. Agar dengan dakwah itu manusia mau mengejar apa yang baik (bernilai positif) dan meninggalkan apa saja yang munkar (bernilai negatif) dalam seluruh segi hidup dan kehidupannya. Karena itu diharapkan, terjadi perbaikan keadaan setiap saat menuju ke arah memperbagus sesuatu hal, hingga sesuai dengan keharusan dan lebih memberikan manfaat bagi kehidupan.

Dengan demikian, dakwah dapat dipandang sebagai usaha menyukai keadaan, sebagaimana yang digambarkan Afif Muhammad (1986: 10) ketika menyambut terbitnya "Islam Aktual" karya Jalaludin Rahmat, sebagai berikut:

"Ajaran Islam, adalah ajaran yang andaikata berhasil diwujudkan dalam kehidupan nyata memang akan membentuk manusia, masyarakat dan bangsa yang sempurna. Kecuali di masa Rasulullah, ajaran Islam yang demikian sempurna itu belum pernah berhasil direalisasikan dalam kehidupan nyata. Zaman klasik dalam babak sejarah Islam yang mencapai puncaknya pada masa Abbasiyah pun, kalau dimatrai dengan ajaran Islam yang terdapat dalam Al-Quran, masih cukup jauh dari harapan. Apalagi masamasa sesudahnya. Bahkan aktualisasi ajaran Islam yang dilakukan kaum muslimin di zaman modern sekarang ini, memperlihatkan kondisi yang masih jauh dari yang dicita-citakan. Islam ideal

Ilmu Dakwah: Academic Journal for Homiletic Studies, Vol. 10 No.1 | Jan-Juni 2016361 
(sebagai ajaran) Islam Aktual, ibarat dua tebing yang terpisahkan oleh jurang yang hingga kini belum berhasil dipengkal " .

Upaya pendangkalan jarak itulah sebagai upaya dakwah. Dan pemikiran kearah itu, merupakan pemikiran dakwah. Agama dakwah seperti Islam, menurut Muller (Arnold: 1981: 1), di dalamnya terdapat upaya-upaya untuk menyebarluaskan ajaran kebenaran dan mengajak orang-orang yang belum mempercayainya sebagai tugas suci. Ditambah lagi ada semangat yang tak kunjung padam dari para penganutnya, sehingga kebenaran itu terwujud dalam pikiran, kata-kata dan perbuatan. Disamping menurutnya, ada semangat yang tak kunjung puas sampai berhasil menanamkan nilai kebenaran itu dalam jiwa setiap orang, sehingga apa yang diyakini sebagai kebenaran diterima oleh setiap manusia.

Keyakinan, apabila ajaran Islam yang mencakup segenap aspek kehidupan dijadikan sebagai pedoman dan dilaksanakan dengansungguhsungguh, juga terdapat di kalangan umat Islam. Dengan demikian diakui bahwa Islam yang Rahmatan Lil Alamin dapat menjamin terwujudnya kebahagiaan dan kesejahteraan umat manusia (Saleh, 1977: 1). Semangat memperjuangkan kebenaran agama inilah yang telah merangsang kaum muslimin untuk menyampaikan ajaran-ajaran Islam kepada penduduk di tiap negeri yang mereka masuki, disamping sebagai kewajiban agama. Hal tersebut merupakan suatu sisi latar belakang adanya dakwah.

Tidak hanya itu, adanya dakwah juga berkaitan dengan perwujudan kebahagiaan dan kesejahteraan umat manusia.Seperti menurut Jamaludin Kafie (1993: 21), bahwa, kelahiran manusia ke dunia dihadapkan kepada pilihan baik dan buruk. Pilihan baik dan buruk perbuatan maupun sikap hidup seseorang yang dilakukan secara sadar, lanjut Jamall, merupakan pilihan dirinya, diman perbuatan itu didorong oleh kehendak (kebutuhan, hasrat, keinginan, cita-cita, nafsu dan kemauan) lahir dalam dirinya dan terbentuk oleh pribadinya, setelah dipertimbangkan oleh perasaan dan Mendapat pengawasan dari pikirannya.

Namun demikian, kemampuan memilih ini sering tidak mudah dilakukan oleh manusia. Sebagaimana Al Ghazali (dalam Othoman, 1987: 121), memandangnya, karena manusia tiba di dunia ini dengan berbagai sifat yang bertentangan dengan berbagai hubungan yang banyak kemungkinan untuk berkembang, mendapatkan sesuatu pemuas diri (tiap unsur), tanpa menghiraukan pribadi yang seutuhnya. Sementara itu, menurut Ghazali, dalam rangka memainkan perannya dalam sesuatu keselarasan yang diperlukan, manusia tiba kedunia ini tanpa memiliki pengetahuan pribadi (yang cukup) untuk menuntun diri dalam pertumbuhannya.

36є Ilmu Dakwah: Academic Journal for Homiletic Studies, Vol. 10 No.1 | Jan-Juni 2016 
Dalam keadaan seperti itu dakwah, dipandang oleh (Kafie, 1993: 27), memberikan dorongan kepada manusia untuk memilih sesuatu yang terbaik dengan memilih agama yang sesuai dengan apa yang dibutuhkan oleh dirinya secara utuh dan mendapat keridhaan dari Allah, yaitu Islam.

Itulah sebabnya Ahmad Watik Pratinya (1994), perlunya dakwah dipahamani, dua Dimensi yaitu dimensi kerisalahan dan kerahmatan. Memahami dakwah dari dimensi kerisalahan (Q.S.6:67;5:104), berarti meneruskan tugas Rasulullah dalam menyeru agar manusia mengetahui, memahami, menghayati (mengimani) dan mengamalkan islam sebagai pandangan hidupnya. Dengan pengetahuan, pemahaman, penghayatan, dan pengalaman tersebut, diharapkan adanya perubahan prilaku manusia, baik individual maupun kelompok, kea rah yang lebih baik. namun demikian, menurut Watik, perubahan prilaku tersebut dimungkinkan, kalau kegiatan dakwah dapat mempengaruhi tata nilai yang dianut oleh individu atau masyarakat. Di samping memberikan makna pada dimensi ini, yaitu mencoba menumbuhkan kesadaran diri dalam individu atau masyarakat, tentang kebenaran nilai dan pandangan hidup islam, sehingga terjadi proses internalisasi nilai islam sebagai nilai hidupnya. Suatu ungkapan lain yang juga memberikan makna pada dimensi ini, sebagai proses mengkomunikasikan nilai-nilai islam. Sehingga apa yang terjadi selanjutnya ialah, islam sebagai sumber nilai dan dakwah sebagai proses alih nilai.

Dalam dimensi kerahmatan, dakwah mengacu pada firma Allah Q.S 21:107, yang artinya: "Dan tidaklah Aku mengutus kamu, melainkan untuk (menjadi) rahmat bagi seluruh alam". Dengan begitu, dakwah bermakna mengaktualkan (merealisasikan) islam sebagai rahmat (jalan hidup yang menyejahterakan, membahagiakan) bagi manusia. Jika dalam dimensi kerisalahan dakwah lebih bercorak mengenalkan Islam agar manusia mau ber-Islam, demikian kata Watik, maka dalam dimensi kerisalahan dakwah berarti mewujudkan Islam dalam kehidupan. Hal ini sekaligus menuntut umat Islam (da'i) untuk membuktikan validitas Islam sebagai rahmat lil alamin. Sehingga karya dakwah tiada lain dari upaya menjabarkan nilai-nilai normatif Islam (dalam Qur'an dan Assunah) menjadi konsep-konsep kehidupan yang dapat dilaksanakan dalam kehidupan sehari-hari, kemudian mengupayakan konsep yang operasional itu dapat diterapkan. Dengan demikian dapat dikatakan, Islam merupakan sumber konsep dan dakwah sebagai operasionalisasi ajaran Islam, sebagai rabmatan lil alamin.

Selain itu, dakwah Islam dilengkapi dengan amar ma'ruf dan nabyil munkar. Ia adalah segala usaha yang ditujukan untuk mengolah kenyataan hidup dan kehidupan manusia, agar mau mengerjakan apa yang (baik,

Ilmu Dakwah: Academic Journal for Homiletic Studies, Vol. 10 No.1 | Jan-Juni 2016363 
bernilai positif) dan meninggalkan segala yang murtad (buruk, bernilai negatif) dalam seluruh kehidupannya. Melalui tindakan tersebut Abu Risman (Achmad, 1985: 13), optimis bahwa disepanjang hidup dan kehidupan manusia akan terjadi proses islab dan ihsan. Usaha untuk perbaikan keadaan atau penetapan sesuatu menurut yang seharusnya, itulah islah. Sedangkan ibsan yang dimaksud ialah usaha kearah memperbagus sesuatu, sehingga lebih memberikan kemanfaatan bagi kehidupan. Hubungan keduanya dengan aspek jasmani manusia akan memberikan kemakmuran material, sedang hubungannya dengan rohani akan mebuahkan kesejahteraan spiritual. Hak ini merupakan isyarat juga bahwa dakwah tidak hanya menyangkut hal yang transenden (babluminallah atau kemurnian agama) melainkan berkenaan pula dengan hal praktis dan realistis seperti halnya kebutuhan manusia pada material atau perubahanperubahan yang terjadi di masyarakat. Suatu konsekuensi bahwa dakwah memiliki sifat dinamis dan elastik, sehingga ia tetap memiliki nilai-nilai fungsional dalam kehidupan manusia.

Dengan demikian, hakikat dakwah Islam adalah mengajak dan meluruskan kembali manusia supaya kembali kepada (jalan) Allah, yaitu kembali kepada hakikat fitri (Q.S.30:30) dimana manusia telah melakukan kesaksian, bahwa Allah adalah Ilah yang sebenarnya. Hakikat fungsi bahwa manusia adalah khalifah-Nya (Q.S. 2:30), serta hakikat tujuan bahwa semua kegiatan manusia selaku khalifah dilaksanakan dalam kerangka ibadah kepada Allah (Q.S 51:56). Sedangkan tehniknya, mengajak manusia untuk kembali kepada fitri, fungsi dan tujuan manusia. Disamping meningkatkan keberimanan serta mengupayakan transformasi iman kedalam bentuk amal shaleh secara nyata dalam kehidupan, melalui tindakan amar ma'ruf nahyil munkar serta ishlah dan ihsan dengan memperhatikan nilai-nilai fungsional yang dinamis. Ketika iman mengalami transformasi menjadi realitas amal shaleh, maka saat itulah khaira al ummah tercipta dan ketika khaira al ummah maka terwujud pulalah kebahagiaan manusia (Q.S 3:110;3:104), sebagai apa yang menjadi tujuan dakwah.

Penelitian mengenai pemikiran dakwah Arhmaedi Mahzar tentang dakwah pada masyarakat teknologi memperoleh hasil sebagai berikut:

\section{Pengaruh Sosio-Historis}

Pemikiran Dakwah Armahedi Mahzar tidak terlepas dari latar belakang sosio-historisnya. Sebagai seorang anak yang berasal dari keluarga minang di rantau, yang secara tradisional bekerja sebagai pegawai negeri, Armahedi mendapat dua jalur pendidikan yang pada waktu itu seolah bertentangan. Pendidikan jalur formal di Sekolah Umum Negeri, membentuknya sebagai seorang yang menilai teknologi, ilmu pengetahuan,

364 Ilmu Dakwah: Academic Journal for Homiletic Studies, Vol. 10 No.1 | Jan-Juni 2016 
filsafat dan ideologi-ideologi modern sebagai puncak kemajuan manusia. Sementara itu jalur pendidikan informal, di rumah, menekankan kemutlakan kebenaran Islam sebagai agama universal yang abadi dan tak berubah-ubah. Di dalam pikirannya timbul suatu pertanyaan, mengapa kalau Islam itu absolut, universal dan abadi dia tidak menguasai dunia? Dalam sekala kecilnya pertanyaan itu menjadi: mengapa handaitaulannya yang mendapat pendidikan Belanda, justru banyak yang melalaikan Islam? Setelah melakukan berbagai wawancara dengan mereka yang dididik secara Barat itu membuat Armahedi berkesimpulan bahwa, walaupun ajaran Islam itu universal, mutlak dan abadi, perumusan dan penyampaiannya selalu bersifat lokal, relatif dan historis, kalangan Barat yang terdidik secara Barat sekuler sering menyerang Islam bukan karena substansinya tetapi dalam formalitas zahirinya.Itulah sebabnya ia lebih tertarik pada ajaran kaum reformis Islam modern seperti berkembang dikalangan Muhammadiyah, ketimbang Nahdatul Ulama yang dipandangnya kolot. Itulah pula yang menyebabkan lebih tertarik masuk Himpunan Mahasiswa Islam yang dipandangnya netral, ketimbang pergerakan Mahasiswa Isalm Indonesia yang Nahdin. Itulah pula sebabnya ia menaruh harapan besar pada pembangunan masjid Salman yang dirintis oleh beberapa mahasiswa dan dosen yang terlibat dalam HMI. Dalam lingkungan modernis ini ternyata, Armahedi mengaku merasa tidak tenang. Dalam pandangannya, kelompok modernis membuang tradisi-tradisi Islam dan kembali ke dalam taks-teks Al-quran dan Hadits yang ditafsirkan secara rasional. Dikalangan modernis tersebut dia sering melihat Islam sebagai filsafat atau Ideologi yang menentang filsafat-filsafat dan ideologi-ideologi Barat, sementara dalam konsep-konsep Barat itu ia melihat adanya kebaikan atau kebenaran. Itulah sebabnya Armahedi tertarik kepada ajaran ideologi Islam yang menyatakan, Islam ada diantara kapitalisme Barat dan sosialisme Timur. Namun, itu pun mengecewakannya, karena menurutnya pada ajaran itu pun, secara tak sadar tidak lebih dari kapitalisme minus plus riba zakat, atau sosialisme minus ateisme plus Tauhid. Mereka yang menganut ajaran ideologi itu menurutnya, tidak menyadari sisi negatif kapitalisme yang dikritik oleh kapitalisme. Ataupun sisi-sisi negatif, baik kapitalisme maupun sosialisme, yang dikritik oleh intelekual baru barat yang mengkritik kedua ideologi itu secara mendasar. Itulah yang dikhawatirkannya. Jika Islam dirumuskan secara begitu, Armahedi khawatir, umat Islam akan terjerumus kepada krisis-krisis psikologis, dan sosial dan lingkungan, yang sama seperti dialami oleh dunia Barat, walau mungkin berhasil menghindari krisi moralnya. Itulah sebabnya Armahedi lalu tertarik kepada gerakan kaum hippies di tahun 1960-an yang ingin kembali pada kehidupan yang seimbang dengan alam.Ia menyayangkan

Ilmu Dakwah: Academic Journal for Homiletic Studies, Vol. 10 No.1 | Jan-Juni 2016365 
gerakan hippies ini sering dilihat dari sisi dekadensi moralnya dari pada kritik sosialnya. Ketika pada tahun 70 -an, terjadi suatu pergeseran pemikiran dunia Barat yang menarik perhatiannya, yaitu beralihnya sudut pandang para kritis generasi muda hippies yang disebut baby boomers ini. Bersamaan dengan bergesernya kebiasaan dari praktek-praktek obatobatan halusinogetik suku Indian ke praktek-praktek meditasi Timur Yoga, Zen dan yang lainnya. Mereka mulai mempertimbangkan sudut pandang spritualisme Timur. Ini cukup mengherankannya, karena, ketika generasi muda Negara-negara Timur sedang mencari pengetahuan modern Barat, justru generasi muda Negara-negara Barat, mencari kebijaksanaan tradisional Timur. Sedangkan generasi muda Islam berpuas diri dengan modernisme Islam. Armahedi merasa resah dengan keadaan itu. Itulah sebabnya disamping mempelajari filsafat dan ideologi Barat, dia juga mempelajari tradisi hikmat Timur. Ketika ia mempelajari semua itu, Armahedi kaget, saat ia menemukan serpihan-serpihan kebenaran islami yang berserakan di sana. Serpihan-serpihan kebenaran Islam yang ditinggalkan oleh pemikir-pemikir Islam modernis. Misalnya kaum modernis yang berkecenderungan fundamentalis cenderung untuk membuang tradisi filsafat Islam yang merupakan akar dasar pemikiran sains dan filsafat Barat modern. Di lain pihak, mereka juga membuang tradisi tasawuf atau mistisisme Islam yang mempunyai paralelisme dengan ajaran spiritual Timur yang kini kembali ditengok oleh generasi muda Barat. Itulah sebabnya kemudian Armahedi mencoba mencari sintesa materialisme sains Barat mozanah tradisional pemikiran Islam sendiri.Sebelum itu dia mengadakan analisis struktural pada ajaran-ajaran filsafat modern Barat.Ternyata dia menemukan pola-pola struktural pada ajaran-ajaran filsafat modern Barat, seperti menurutnya, yang ditemukan oleh antropolog Perancis, Claude Levis Strauss dibalik mitologis sukusuku Indian primitif di Amerika Selatan. Yang mencengangkan Armahedi ialah kenyataan bahwa dengan dirumuskannya kerangka dasar pemikiran Barat modern itu secara geometris struktural, ternyata komponenkomponen ajaran Islam secara tradisional, secara natural dapat diintegrasikan dengan struktur pemikiran Barat tersebut. Hal ini menunjukan bahwa ajaran Barat tidak lebih dari pada serpihan-serpihan kebenaran universal Islam.Lebih mencengangkannya lagi, ialah kenyataan bahwa setelah dilakukan transformasi struktural prisma-prisma geometris itu menjadi satu matriks kemanusiaan, segera nampak bahwa matriks humanistik itu tak lebih dari bagian matriks realitas yang lebih besar lagi yang meliputi manusia, alam dan Sang Penciptanya. Kemenarikan itu akhirnya tersimpul dalam kerangka materik realitas dalam suatu struktur kesatuan integral realitas yang merupakan intisari ajaran-ajaran mistik

36c Ilmu Dakwah: Academic Journal for Homiletic Studies, Vol. 10 No.1 | Jan-Juni 2016 
timur. Dengan begitu Armahedi telah menemukan sintesa islami antara sains dan filsafat Barat dengan kearifan dan ,mistik Timur. Sintesa itru kemudian disebutnya Integralisme sesuai dengan usul salah seorang rekan diskusinya, Pak Aldy Anwar, yang juga rekan tempat mencurahkan penemuan-penemuan intektualnya tersebut.

\section{Filosofi di Balik Teknologi}

Bahwa Teknologi membawa dampak kepada Masyarakat. Armahedi memandang dampak itu bisa berarti positif bisa juga negatif. Dampak juga bisa di sengaja sesuai tujuan semula, atau yang tidak disengaja, yang tidak diperkirakan sebelumnya. Dampak itupun bisa langsung dirasakan namun banyak juga yang membutuhkan waktu untuk merasakannya. Dampak positifnya, menurut Armahedi bahwa teknologi pada satu pihak telah membawa manusia ke puncak kemajuan, hampir semua keinginan manusia yang bersifat fisis telah terpenuhi dan berkualitas tinggi. Teknologi Industri membawa kemakmuran. Namun bersamaan dengan itu ia juga melihat bahwa industrialisasi pun berakibat lain. Dari kemajuan teknologinya telah membawa efek rumah kaca, polusi udara, menipisnya lapisan ozon, kehancuran aneka ragam hayati lingkungan artifisial serba batu, semen dan besi berbagai krisis lingkungan lain yang membuat wajah bumi semakin lusuh dan suram. Kemakmuran yang dibawa oleh industrialisasi umpamanya, ternyata juga meminta korbankorban yang tidak kecil.

Dalam tahapan yang berkelanjutan pengorbanan yang dituntut itu justru kemanusiaan itu sendiri. Bahwa suatu sitem budaya global menyebar melalui jaringan komunikasi dunia sebagai sistem syaraf vegetatif megaorganisme teknik sehingga mega organisme teknik benar-benar menjadi mekanik dan mandiri. Dalam kondisi seperti itu sel-sel megaorganisme teknik bukan lagi manusia melainkan mesin-mesin manusia paling-paling menjadi sel-sel reproduktif atau organ sex megaorganisme mekanik. Lebih lanjut menurut Armahedi teknosfer (lingkungan fisik terdiri dari semua peralatan yang digunakan dan dihasilkan oleh lembaga masyarakat yang melaksanakan pemanfaatan pelestarian dan pengembangan teknologi) bukan lagi menjadi suatu megaorganisme teknik, tetapi suatu mega mesin di mana manusia tidak lebih dari chip-chip yang menghubungkan suatu komponen dengan komponen lainnya agar manusia dapat berperan, maka manusia harus menjadi mekanis lengan menjadi spealis-spealis mekanistik yang hanya menggunakan sebagian kecil dari potensi kemanusiaan, sebagai organisme yang paling plastis dimuka bumi ini itulah nampaknya yang sering dikatakan dehumanisasi oleh banyak orang. Manusia jadi terasing dari alam, terasing dari satu sama lain. Inilah pula yang disebutkan bahwa salah

Ilmu Dakwah: Academic Journal for Homiletic Studies, Vol. 10 No.1 | Jan-Juni 2016367 
satu gambaran masyarakat mendatang akan tumbuh suburnya individualisme termasuk dalam keberagaman. Menghadapi hal itu langkah yang paling awal adalah meninjau secara kritis. Dalam sikap itulah Armahedi melihat bahwa teknologi berkembang cepat setelah terjalinnya tiga macam proses teknosifikasi yaitu humanisasi, rasionalisasi dan humanisasi.

Pada gilirannya inilah yang dianggap oleh Armahedi sebagai penyebab keterasingan manusia dari lingkungannya dan bahkan dari dirinya sendiri, yang seharusnya dipelajari secara utuh dan menyeluruh. Apalagi ketika Armahedi juga melihat sekularisme yang berkaitan erat dengan perkembangan ekonomi memiliki peran yang sangat dominan. Ketika ekonomi menyangkut kegiatan manusia untuk meningkatkan materinya di dunia, maka semakin banyak urusan menyita kehidupan manusia diselesaikan oleh teknologi yang merupakan urusan keduniaan tersebut sementara tidak seimbang dengan penyelesaian keagamaan. Hal itu timbul akibat lahirnya materialisme. Persoalannya menjadi lain. Materialisme mengaggap materi sebagai realitas dasar, materi dianggap ada sebelum jiwa.

Armahedi memandang secara kritis terhadap realitas keberadaan masyarakat yang diliputi oleh kemajuan teknologi yang merupakan wujud kebudayaan manusia yang paling luar dan paling nampak. Pada lapisan dalamnya ternyata terdapat dominasi humanisme dalam tata nilai kehidupan mereka dominasi rasionalisme dalam sistem pengetahuan mereka dan dominasi materialisme dalam pandangan dunia mereka atau dalam istilah lain ada dominasi humanisme aksiologi, dominasi rasionalisme dalam epistemologi dan dominasi materialisme dalam ontologi. Semua itu kini nampak nya telah menyerap kealam bawah sadar manusia sehingga dominasinya pun telah ada dibawah sadar kebanyakan manusia. Tentunya suatu yang tidak mungkin dibiarkan begitu saja semakin larut oleh para penegak dakwah. Akan tetapi bagaimana dan siapa kiranya penegak dakwah yang lebih pantas untuk menanggulangi itu semua, itu pula yang menjadi sorotan Armahedi dalam bahasannya berikut.

\section{Dakwah pada Masyarakat Teknologi}

Adapun pemikiran Armahedi Mahzar tentang dakwah pada masyarakat Teknologi ialah bahwa satu-satunya cara untuk menanggulangi krisi ilmu pengetahuan dan teknologi dewasa ini ialah mengembalikan kepada tampuknya yang asli. Suatu ungkapan yang secara tidak langsung menempatkan pandangan Armahedi sejajar dengan pemikir-pemikir Barat yang lain. Seperti halnya Thomas Khun yang menyatakan bahwa jika ilmu sudah dianggap falid lagi atau tidak mampu menjawab kebutuhan zaman akan ditinggalkannya oleh para pengembangnya. Armahedi lebih

36६ Ilmu Dakwah: Academic Journal for Homiletic Studies, Vol. 10 No.1 | Jan-Juni 2016 
memandang secara lebih mengakar dengan melihat ilmu dari dasarnya. Ia melihat ilmu Islam terdiri dari tiga kelompok besar, yaitu ilmu kealaman, ilmu kemanusiaan, dan ilmu keagamaan. Ketiga-tiganya menunjukan hirarki epistemologis ilmu manusia disamping mencerminkan hirarki ontologis alam, manusia dan Tuhan. Itu merupakan objek pengetahuan manusia.

Disamping itu Armahedi memandang adanya hirarki metodologis, panca indra, akal, dan wahyu. Dengan kata lain, persepsi konsepsi dan relevansi yang merupakan sumber-sumber utama ilmu pengetahuan manusia. Sehingga antara sains ada keterkaitan antara filsafat dan aqidah yang merupakan epistimologis. Sebagai ilmuwan muslim, Armahedi melihat kepongahan dalam sains Barat. Dimana karena kepongahan itu telah menimbulkan mitos kenetralan ilmu termasuk ilmu-ilmu kemanusiannya yang kemudian segera diikuti oleh kenetralan teknologi. Karena sering mengaburkan realitas pada segelintir umat yang mendominasi kekuasaan dan ekonomi. Dalam hal ini, Armahedi tetap menekankan pentingnya suatu upaya pengembalian Iptek pada tampuknya, yaitu sains dan teknologi yang berlandaskan kepada nilai-nilai Tauhid. Jelaslah bahwa Armahedi, memiliki pandangan yang mengakar dalam hal ini. Ia tidak puas dengan suatu langkah yang hanya bersifat penanggulangan permukaannya saja, melainkan, ia ingin yang lebih tajam, dan karenanya dianggap lebih menjadi jawaban tuntas.

Adapun strategi Dakwah berikutnya Armahedi melihat pentingnya tiga hal. Pertama, Integralitas sosok da'i. Armahedi memandang pelaku dakwah yang pantas menduduki garda terdepan pada masyarakat teknologi. Cendikiawan muslim atau yang lebih dia pahami dari Al-Quran sebagai Ulil Albab merekalah yang hendaknya berada disana. Sebaliknya para da'i yang telah ada hendaknya mereka mengacu untuk memiliki apa yang merupakan ciri dari Ulil Albab tersebut. Oleh karena itu, Armahedi memandang perlu pula adanya upaya peningkatan dalam bidang sumber daya manusia bagi pelaku dakwah.

Kedua, Integralitas gerakan dakwah. Menurut Armahedi, gerakan dakwah tidak mungkin akan membawa kepada kebangkitan, selama mereka terpisah secara satu sama lain. Armahedi menganggap bahwa selama masalah Dienul Islam digarap oleh kaum fundamentalis dalam gerakan tajdid, masalah hikmat digarap oleh kaum modernis secara sporadis. Sedangkan masalah tamtamdun digarap oleh kaum tradisionalis. Dengan kondisi mereka yang terpisah-pisah, apalagi jika sampai pada permusuhan. Maka Armahedi memperkirakan gerakan-gerakan mereka akan berakhir dengan retak-retaknya kesatuan umat. Suatu kondisi yang dengannya tidak mungkin kebangkitan umat akan tercapai. Hanya dengan

Ilmu Dakwah: Academic Journal for Homiletic Studies, Vol. 10 No.1 | Jan-Juni 2016369 
bersatunya para fundamentalis dan modernis kota dengan para tradisionalis desa di satu pihak, dan dengan bersatunya para pemuka agama, apapun alam pikirannya, dengan nestapa rakyat jelata pemeluk agamanya, di lain pihak, Armahedi memandang, umat Islam akan bangkit. Di dalam hal ini ia member solusi untuk berbagi kepemimpinan sesuai dengan spesialisasi masing-masing gerakan.

Ketiga, Integralitas strategi Dakwah. Dalam hal ini perdaban merupakan pusat dari titik pandang Armahedi dalam menentukan strategi dakwahnya. Dimana peradaban didalam Islam terdiri dari dua buah pilar yaitu masyarakat dan diri pribadi. Masing-masing pula terdiri dari empat lapisan dimana masing-masing lapisnya adalah subsistem dari masyarakat dan pribadi. Subsistem materi adalah lapisan teratas, sedang subsistem terbawah adalah nilai-nilai. Lapisan energi menurut Armahedi berada diatas lapisan yang menyangkut energi.Energi menyangkut diatas lapisan informasi, sedang informasi menyangkut pada nilai-nilai tersebut. Suatu ciri yang dipandang oleh Armahedi merupakan ciri peradaban Islam bahwa ia dibangun di atas sebuah landasan kalimat Lailabaa ilallah Mubammaddurrasulullah.

Dari pandangan tersebut, maka strategi yang dapat digunakan dalam berdakwah, ada tiga strategi utama. Pertama, strategi dari atas ke bawah (secara berturut-turut, koordinasi, komunikasi dan komuni). Kedua, srategi dari bawah keatas (secara berurutan dari komuikasi gagasan, koordinasi kegiatan dan integrasi alat di bawah suatu program bersama. Ketiga, strategi langkah serempak semua yang diatas dilaksanakan secara serempak. Dimana masing-asingnya dapat dilakukan dalam tingkat local nasional, tingkat regional ataupun tingkat global. Pada tingkat wilayah ini Armaahedi mencermati tiga ragam lagi. Pertama, ragam peleburan (dimana strategi utama dimulai pelaksanaannya dari pusat glonal, lalu disebarkan secara bertahap ke pusat-pusat regional, nasioanal, regional dan global.Sedang yang ketiga, ragam penyelimutan (strategi utama yang dilakukan di semua tingkat secara serempak).

Itulah pandangan kritis Armahedi dalam strategi dakwah global. Selanjutnya pandangannya dengan lebih bersifat operasional. Pertama, proses komuni, yang dapat berarti pembentukan jaringan dakwah untuk melatih, menatar dan tukar menukar da'i .Kedua, proses komunikasi, yang dapat berarti, penyelanggaraan konferensi-konferensi, seminar, penerbitan jurnal, pembentukan kantor-kantor berita Islam dan berbagai jaringan jasa informasi yang seluruhnya dikuasai oleh umat Islam.Ketiga, proses koordinasi, yang dapat pembentukan perhimpunan-perhimpunan Islam untuk berbagai bidang profesi dan bidang usaha. Keempat, proses integrasi, yang dapat berarti brupa pembentukan badan-badandan serikat

37( Ilmu Dakwah: Academic Journal for Homiletic Studies, Vol. 10 No.1 | Jan-Juni 2016 
usaha islam untuk berbagai macam kepentingan (bank, perusahaan angkutan udara, laut dan darat, dan sebagainya). Langkah strategi tekniknya: Pertama, pembuatan jaringan-jaringan kerja antar kelompokkelompok kegiatan sejenis masjid-masjid, di kampus-kampus kota, pesantren-pesantren desa, untuk tukar-menukar pengalaman kerja dan gagasan-gagasan. Kedua, membuat pertemuan berkala antar kelomokkelompok kegiatan yang berlainan jenis untuk menghasilkan sisnegi kreatif antar berbagai jenis kegiatan. Ketiga, diadakan artikulasi keberhasilankeberhasilan kelompok kegiatan pemecahan masalah kedalam suatu kerangka konseptual islam, keempat, penerjemah kembali kerangka konseptual tadi, menjadi program-program kerjasama antar kelompok kegiatan dengan skala yang lebih besar. Kelima, melakukan evaluasievaluasi hasil kegiatan kelompok yang menikngkatkan kecerdasan dan kesejahteraan umat berdasarkan kriteria keserasian dengan nilai-nilai Islam. Keenam, pengurangan secara bertahap hal-hal yang berlawanan dan bertentangan dengan nilai-nilai Islam.

Dengan melalui tahapan-tahapan itu, Armahedi merasa yakin bahwa, ia akan dapat menjadi strategi dakwah pada masyarakat teknologi.

\section{PENUTUP}

Kesimpulan dari hasil penelitian menunjukan bahwa, Pertama, Pemikiran dakwah Armahedi Mahzar tidak terlepas dari latar belakang sosio hitoris kehidupannya yang terbiasa merantau dan pendidikan agama dan umum, yang perbedaannya ia padukan. Kedua, Pandangan Armahedi mengenai teknologi erat kaitannya dengan bentuk filosofi di balik teknologi tersebut. Ketiga, Pandangan dakwah Armahedi pada masyarakat teknologi, diperlukan langkah tazkiyatunnafs pada tingkat individu; Sabar dan syukur pada tingkat kelompok, zuhud dan faqr pada tingkat masyarakat, serta pengembangan Sains berlandaskan Tauhid.

Adapun sebagai saran dari penelitian ini: Pertama, kepada pemangku kebijakan akademik, terutama yang terkait dengan pengembangan keilmuan dakwah, penelitian sejenis (pemikiran dakwah) merupakan suatu yang perlu terus digalakan. Hal itu mengingat, pertama, bahwa masih banyaknya pemikiran dakwah dari para tokoh dakwah, termasuk para praktisi dakwah dalam berbagai kategori garapan dakwah, yang belum terungkap secara sistematis. Kedua, kerangka teoritik dakwah isinya masih relatif sedikit, sehingga sangatv membutuhkan banyak masukan dan pengisian isi dari berbagai kategori kajian dakwah. Dengan memperbanyak penelitian sejenis, kiranya bisa menambah masukan bagi pengayaan khazanah konsep maupun teoritik dakwah dimaksud. Kedua, kepada para peneliti, penelitian ini mengungkap tentang salah-satu sisi

Ilmu Dakwah: Academic Journal for Homiletic Studies, Vol. 10 No.1 | Jan-Juni 2016371 
pemikiran strategi dakwah di kalangan masyarakat teknologi, dari seorang tokoh, Armahedi Mahzar. Sepengetahuan peneliti masih banyak peluang untuk mengungkap pemikiran tokoh dakwah lain, untuk strategi dakwah pada wilayah objek dakwah yang lain. Misalnya strategi dakwah untuk masyarakat pikiran, masyarakat terpencil, masyarakat pasar, komunitas diskotik, dan sebagainya. Semua itu peneliti anggap penting, untuk membangun keutuhan bangunan Ilmu Dakwah yang lebih kaya dan mampu menjadi perspektif. Ketiga, kepada para praktisi dakwah, hasil penelitian ini kiranya dapat memberikan setetes sumbangan pemikiran untuk menata aktivitas dakwah, ketika berhadapan dengan masyarakat teknologi. Sehingga dengan pemahaman para praktisi dakwah mengenai tema penelitian ini, dapat mempersiapkan segala sesuatunya secara lebih baik, sehingga dakwah pada masyarakat teknologi bisa berjalan secara efektif, efisien, berdaya guna dan berhasil guna.

\section{DAFTAR PUSTAKA}

Achmad, Amrullah, Dakwah Islam dan Transformasi Sosial Budaya, Yogyakarta: PLP2M, 1985.

Al-Bahiy, Muhammad, Pikiran Islam Modern, Jakarta: Pustaka Panjimas, 1986.

Al-Qodiry, Marwan, Seimbanglah dalam Beragama, Jakarta:GIP, 1983.

Amsyari, Fuad, Masa Depan Umat Islam Indonesia, Bandung: Al-Bayan, 1993. 1990.

Amal, Taufik Adnan, Islam dan Tantangan Modernitas, Bandung: Mizan, 1993.

Amin, Samsul Munir, Ilmu Dakwah, Jakarta: Amzah, 2009.

Arnold, Thomas W, The Preaching of Islam. Jakarta: Widdjaya, 1981.

Bakar, Osman, Taubid dan Sains, Bandung: Pustaka Hidayah, 2008.

Baiquni, Ahmad, Islam dan Ilmu Pengetabuan Modern, Bandung: Pustaka, 1983.

Bagir, Haidar (peny), Benturan Barat dengan Islam, Bandung: Mizan, 1983.

-----------, Menuju Persatuan Umat (Bandung: Mizan, 2012

Enjang AS, Dasar-dasar Ilmu Dakwah, Bandung: Widya Pajajaran, 2009.

Gharishah, Ali, Wajah Dunia Islam Kontemporer, Yogyakarta: Al-Kautsar, 1989.

Haryanto, Rasulullah Way Of managing Poeople, Jakarta: Khalifa, 2008.

Hilal, Syamsu Hilal, Gerakan Dakwah di Indonesia, Jakarta: Tarbiatuna, 2003

37_́ Ilmu Dakwah: Academic Journal for Homiletic Studies, Vol. 10 No.1 | Jan-Juni 2016 
Dakwah pada Masyarakat Teknologi

Ibrahim, Marwah D, Teknologi, Emansipasi dan Transedensia, Bandung: Mizan, 1994

Idris, Ja'far S, 1991, Islam dan Perubahan Sosial, Bandung: Mizan, 1991

Karim, Rusli, Agama dan Masyarakat Modern, Yogyakarta: Widjaya Mandala, 1992

Kafie, Jamaludin, Psikologi Dakwah, Surabaya: Indah, 1993.

Koencaraningrat, Antropologi, Jakarta: Rineka Cipta, 1990.

Kusnawan, Aep. Ilmu Dakwah: Tinjanan Berbagai Aspek, Bandung: PBQ, 2004

2004.

, Komunikasi Penyiaran Islam, Bandung: Benang Merah Press.

, Manajemen Pelatihan Dakwah, Jakarta: Rineka Cipta, 2009.

-,dkk, Dakwah Multiperspektif, Bandung: Rosda, 2014

Muhammad, Afif, (Ed), Taubid, Dunia Ilmu: Bandung, 1986

Muhyidin, Asep, Metode Pengembangan Dakwah, Bandung: Pustaka Setia, 2002

Mazhar, Armahedi, Integralisme,Bandung: Pustaka, 1983

---------, Islam Masa Depan, Bandung: Pustaka, 1993

, "Dari Mitologi ke Imagologi: Sebuah Reinterpretasi Sestimo Analisis", Mozaik, Vol 3 No. 11993. , "Umat Islam Menghadapi Abad 21", Salman Kau, Dzulqaidah, $1414 \mathrm{H}$. -, "Post Modernisme dan Islam: Telaah Kritis Refleksi Budaya Barat Kontemporer", Makalah, 14 Ramadhan 1414 H. , "Menghadapi Masa Depan Islam: Telaah Kritis Refleksi Religio Kultural”, Makalah Diskusi Himada, IAIN Bandung, 1993. 1993. , "Menuju Masyarakat Informasi", Makalah, agustus, , "Teknologi dan Islam: Refleksi Sebuah Pengantar", Makalah, Bahan Pengantar Buku, 1994.

Madjid, Nurcholish, Islam Kemodernan dan Keindonesiaan, Mizan, Bandung, 1992.

Nashr, Seyyed H, Menjelajah Dunia Modern, Bandung: Mizan, 1994

Natawidjaja, Rochman, Pendekatan-pendekatan Dakwah Kelompok, Bandung: Dipenogoro, 1989

Nottingham, Elizabeth K., Agama dan Masyarakat, Jakarta: Raja Grafindo, 1993.

Othoman, Ali Isa, Manusia Menurut al-Ghazali, Bandung: Pustaka, 1987.

Polak, JBAF Mayor, Sosiologi, Jakarta: Ichtiar Baru, 1976.

Praja, Juhaya S., Aliran-aliran Filsafat dari Rasionalisme bingga Sekularisme, Bandung: Alva Gracia, 1987.

Ilmu Dakwah: Academic Journal for Homiletic Studies, Vol. 10 No.1 | Jan-Juni 2016373 
Pratiknya, Ahmad Watik, "Islam dan Teknologi Pendekatan Lima Digit", Makalah, TT.

"Dakwah Antisipasi bagi Perubahan Sosial Masyarakat Modern, Media Dakwah", 1992.

Puteh, Jakfar, Dakwah di Era Globalisasi: Strategi Menghadapi Perubahan Social, Yogyakarta: AK Group, 2006

Ridwan, Kafrawi, Metode Dakwah dalam Menghadapi Tantangan Masa Depan Islam, Jakarta: Goldan Trayon, 1991

Romli, Dakwah Menghadapi Tantangan Baru, Jakarta: Bina Rena Pariwara, 2001

Rusli, Karim, Agama dan Masyarakat Industri Modern, Yogya: Media Widjaya, 1992.

Sabri, Mohammad, Keberagamaan yang Saling Menyapa, Yogyakarta: Ittaqa, 1999

Saleh, Rosyad, Management Dakwah Islam, Bulan Bintang,:Jakarta, 1977.

Sambas, Syukriadi, Pohon Ilmu Dakwah, Bandung: KP Hadid, 2004

Suparta, Munjir, Metode Dakwah, Jakarta: Kencana, 2003

Soekanto, Soerjono, Sosiologi suatu Pengantar, UI, Jakarta, 1969.

Syukri, Asmuni, Dasar-dasar Strategi Dakwah, Al-Ikhlas, Surabaya, 1983,

Santoso, Budhi," Pandanganm Dunia, Perintah Moral dan Keharusan Menghidupkan Peran Kritikal Kenabian", Makalah, Mizan, Bandung, 1993.

Thalib, Muhammad, Melacak Kekafiran dalam Berfikir, Pustaka al-Kautsar, 1991

Widjaya, Mangun, Teknologi dan Dampak Kebudayaan, YOI, Jakarta, 1983

Zibair, Achmad Charris, 2001, Dari Kematian ke Epistemologi Dakwah, (Yogyakarta: Philosophy Press) 